\title{
Telenovela e Islã: dos estereótipos à visibilidade ${ }^{1}$
}

\author{
Soap opera and Islam: from the stereotypes to visibility
}

\author{
Francirosy Campos Barbosa Ferreira*
}

\begin{abstract}
Resumo
O objetivo deste artigo é apresentar reflexões sobre o núcleo muçulmano da telenovela $O$ Clone, que foi exibida entre outubro de 2001 e junho de 2002, na Rede Globo de Televisão, tendo sua primeira reprise iniciada em janeiro de 2011. Escrita por Gloria Perez, autora conhecida pela abordagem recorrente de temáticas "étnicas" (abordando grupos ciganos, muçulmanos e indianos) e de questões sociais pertinentes (como transplante de órgãos, alcoolismo, imigração ilegal e clonagem humana). 0 argumento que sustento é que a novela "salvou" a comunidade islâmica brasileira da "invisibilidade" e trouxe para dentro das casas brasileiras um pouco da cultura árabe-islâmica, que embora estereotipados, contribuíram significativamente para revelar à nossa sociedade quem são os muçulmanos e em que eles acreditam. Ao escrever o artigo me deparei com outro tipo de "invisibilidade", os quase inexistentes trabalhos em antropologia visual que contemplam análise de imagens de telenovelas. Neste sentido, este texto busca contribuir com outros modos de ver a televisão, em particular, a telenovela.
\end{abstract}

Palavras-chave: telenovela; antropologia visual; gênero; O Clone.

\begin{abstract}
This article presents reflections on the Muslim core of the soap opera named "The Clone", shown between October 2001 and June 2002, on Globo TV, whose reprise started in January 2011. This soap opera was written by Gloria Perez, author known for his ethnic and socially oriented themes, such as Gypsies, Muslims, Indians, organ transplantation, alcoholism, illegal immigration, human cloning, etc. The argument supported by this paper is that such soap opera "saved" from the "invisibility" Brazilian Muslim community and brought into the Brazilian houses some of the Arab-Islamic culture, which although stereotyped, significantly contributed to reveal to our society who Muslims are and what their belief is concerned about. When writing the article I came across another type of "invisibility", the almost non-existent research in visual anthropology of soap operas that would include image analysis. Thus, this text seeks to contribute to other ways of seeing the television in particular soap operas.
\end{abstract}

Keywords: Soap opera; visual anthropology; gender; The Clone.

Artigo recebido em 31 mar. 2015 e aprovado em 30 de maio de 2015.

* Doutora em Antropologia, professora do departamento de psicologia, FFCLRP, USP. País de origem: Brasil. E-mail: francirosy@gmail.com.

${ }^{1}$ Agradeço as leituras preciosas de Sylvia Caiuby Novaes e Luana Baumman. 
Através do olhar a televisão domina silenciosamente todos os sentidos... Adauto Novaes (1991, p.85).

\section{Introdução}

Busco neste artigo tecer algumas considerações sobre o núcleo muçulmano da telenovela $O$ Clone e explorar a problemática na qual são construídas representações deste grupo. A representação, conforme nos apresentou Aumont (2009, p.103), é um processo pelo qual se institui um representante que, em certo contexto limitado, tomará o lugar do que representa. Pretendo, assim, elucidar pontos que contribuam de maneira profícua com e para o discurso televisivo.

As telenovelas da Rede Globo de Televisão ou, porque não dizer, qualquer telenovela que apresente uma audiência considerável, acabam por ditar moda, estabelecer novos comportamentos e mesmo expressões orais (como inshAllah ou Harebaba), ademais de influenciarem até mesmo a produção de mercadorias. Enfim, passam a estar na "boca do povo" e, de tal modo, que se tornam assunto nas famílias, nas mesas de bares, em ambientes de trabalho. Essa dimensão social da novela possibilita que a mesma integre o cotidiano do grupo que lhe é (tele)espectador, o que os próprios índices de audiência expressam, na medida em que há casos de telenovelas que alcançaram em torno de 60\% de audiência no último capítulo. Até o horário de transmissão das telenovelas foi alterado para se adequar à rotina diaria dos espectadores: a novela das oito (2oh), agora é transmitida às 21h, além de introduzirem uma indicação etária - para maiores de doze anos.

A telenovela em questão - O Clone - foi ao ar entre $1^{0}$. de outubro de $2001 \mathrm{e}$ 15 de junho de 2002, na Rede Globo, em horário nobre, e foi reapresentada pela primeira vez no Vale a Pena Ver de Novo, no horário das $15 \mathrm{~h}$, a partir de 10 de janeiro de 2011 a Setembro de 2011. Novela escrita por Gloria Perez, autora conhecida pelos temas "étnicos" e de cunho social que desenvolve, a saber: 
ciganos, muçulmanos, indianos, transplante de órgãos, alcoolismo, imigração ilegal, clonagem humana, tráfico de pessoas, etc.

O Clone registrou média de 62 pontos de audiência em seu último capítulo e fechou com média geral de 47 pontos, sendo exportada para 91 países. Em maio de 2008, a TV Globo e a Telemundo Studios selaram acordo para uma versão em espanhol com atores hispânicos. Foi recorde de audiência em Kosovo. Até então havia sido a maior audiência da Rede Globo em horário nobre. Em Portugal a novela foi transmitida pelo SIC (Sistema Independente de Comunicação), obtendo sucesso de audiência, e para Valdigem (2005) possibilitou "descontruir estereótipos negativos” sobre os muçulmanos residentes em Portugal.

No Brasil não foi diferente, sobretudo diante da consonância temporal de sua transmissão com os atentados de 11 de Setembro, o que instigou fortemente a curiosidade no núcleo muçulmano da novela. Aos pesquisadores de Islam e de contextos árabes, por sua vez, $O$ Clone também despertou interesse. Na minha trajetória acadêmica, o início da transmissão da novela aconteceu em período posterior à defesa de minha dissertação de mestrado, o que possibilitou depois o estabelecimento de conversas bastante informais com as muçulmanas da Mesquita do Pari, onde havia realizado minha pesquisa de campo. Conversas que preencheram meu caderno de campo, que retomei quando da reprise da novela em 2011. Neste momento, entretanto, as redes sociais (re)dinamizaram as discussões e o debate ficou mais intenso, o que busquei acompanhar de perto, de modo que aqui resgato algumas narrativas de interlocutores ${ }^{2}$, seja via pesquisa presencial em 2001, ou via rede, em 2011, com a construção do blog http://francirosy.tumblr.com/

\footnotetext{
${ }^{2}$ Em 2011, o noticiário crescente em relação às comunidades muçulmanas voltou à tona com o assassinato do líder do Al-Qaeda Osama Bin Landen - e enquanto a sociedade discutia se deveriam ou não mostrar a imagem do corpo do suposto mandante do atentando do World Trade Center, a telenovela aumentava o seu ibope.
} 
Parto do pressuposto de que a novela permitiu que a comunidade islâmica brasileira adquirisse visibilidade, além de levar às casas dos espectadores um pouco da cultura árabe-islâmica, ainda que de modo estereotipado (MONTENEGRO, 2004; PINTO, 2010). No entanto, ao escrever o artigo me deparei com outro tipo de "invisibilidade", os quase inexistentes trabalhos em Antropologia Visual - concebida aqui em seu sentido amplo, considerando não só a imagem, mas o som, o texto, o figurino, e como tais elementos representam determinados grupos - que contemplem análise de imagens de telenovelas. Neste sentido, busco ampliar os modos de ver a telenovela na Antropologia, para além das análises sobre recepção, consumo, gênero, etc. Quanto à Antropologia visual, especificamente, indago em que medida a ausência de trabalhos dedicados a narrativas televisas, de modo geral, expressaria uma rejeição etnográfica, tal como apontado por Abu-Lughod (2001, p. 104).

\section{A telenovela e seus interstícios fictícios: um olhar sobre 'O Clone'.}

\section{Foto 1 - Chamada da Novela}

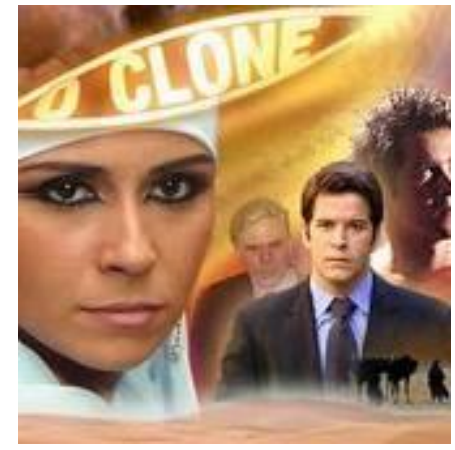

Fonte: CADERNOS DE DANÇA, 2015

Clifford Geertz considera as narrativas antropológicas (etnografias) como interpretações de segunda, de terceira mão - na medida em que a primeira interpretação seria acessível apenas aos nativos e estes, por isso, quando da reconstrução de suas experienciais, acabariam por interpreta-las também - de modo que os textos etnográficos constituiriam ficções; no sentido de que são 
"algo construído", "algo modelado" (1989, p. 25-26). Podemos conceber as telenovelas a partir dessa perspectiva, ou seja, como algo construído e modelado conforme a audiência. E se a audiência é numerosa, deve-se considerar que o que está em jogo é a verossimilhança, que faz com que emissor e receptor compartilhem as mesmas significações do discurso, ao que Borelli (2001) denominou repertório compartilhado:

Em que produtores, narrativas e receptores - reiterando: situados em diferentes posições de classe social, gênero, geração, etnia e formas de subjetivação - encontram-se articulados, conflituosamente, numa cadeia de mediações que não dilui hierarquias, mas também não exclui nenhum de seus elementos da composição desta totalidade (BORELLI, 2001, p. 35).

Esther Hamburger (2007) afirma que as telenovelas se tornaram grandes termômetros da vida cotidiana e dos costumes da sociedade, mostrando a vida privada para o grande público. O espectador se vê nas personagens e se identifica com a atuação. Para compreendermos o que produzem é preciso olhar também para o cotidiano, mas não só. Se elas carregam um componente que as integram, isto é, que falam de amores impossíveis, de ricos e pobres, de conflitos e problemas sociais, podemos considerar que tratam da vida por meio de lentes de aumento, mas no fundo versam sobre nós mesmos, sobre nossas idiossincrasias.

A estreia da telenovela, a menos de um mês após o fatídico atentado, trouxe à comunidade brasileira aquilo que se chamou de cultura da harmonia (NADER, 1990; GOMES, 2002), dispositivo que opera a partir dos princípios ideológicos da harmonia cristã, contudo, constitui um mecanismo nada ingênuo e, por isso, é preciso estar atento às hierarquizações e coações que ele estabelece, assim como as suas potencialidades de instituição de controles sociais.

Se já é evidente que a televisão constitui um universo privilegiado aos antropólogos, o quê e como (d)escrever narrativas antropológicas acerca de telenovelas? Aposto aqui uma inserção importante a ser observada pela 
antropologia visual brasileira: telenovela também é um produto imagético. De que forma e com quais instrumentos teórico-metodológicos devemos nos deter nessas imagens?

Gonçalves e Head (2009, p. 9) dão pistas da análise de audiovisuais ao imaginar a etnografia como um ciborgue e, neste sentido, as mídias fotográficas, fílmicas, vídeos-digitais e o imaginário 'imagético', que elas animam, já fazem parte do corpo etnográfico-ciborgue que conecta a Antropologia ao mundo dos outros e às representações e apresentações que estes outros fazem de seus mundos e do(s) nosso(s). Desconsideram, no entanto, a televisão e, consequentemente, a telenovela, as quais acredito que não só devem ser incluídas, mas também consideradas em suas especificidades, sobretudo no que concerne à construção de representações do outro.

As análises produzidas sobre telenovela no Brasil estão em sua maioria no campo das Comunicações, sendo também, às vezes, produzidas por antropólogos (HAMBURGER 2007; ALMEIDA, 2007; ORTIZ, BORELLI \& RAMOS, 1989; LEAL, 1986), que se dedicaram em sua maioria aos estudos de recepção, consumo, etc., e não à análise de imagem ou de elementos estéticos que compõem uma narrativa da teledramaturgia.

Já se passaram mais de 50 anos do surgimento da televisão e da telenovela, consequentemente. A primeira delas, Sua vida me pertence, de Walter Foster, foi ao ar na extinta TV Tupi, em 1951, e permanece, até hoje, como uma de suas principais atrações, no entanto, segundo Borelli (2001, p. 2) "a academia levou cerca de três décadas para começar a refletir sobre o lugar ocupado pela telenovela no campo cultural brasileiro e na vida cotidiana dos receptores”. O que a autora constata é certo "preconceito acadêmico" em relação ao tema:

As razões que justificam a afirmação acima referida, sobre a existência de um certo preconceito acadêmico diante do fenômeno das telenovelas, residem no fato de que, neste debate, cultura sempre foi considerada sinônimo de culto, erudito. Ainda que se tenha preservado, no contexto acadêmico, um espaço para a análise de manifestações da cultura popular 
- compreendida como tradições, raízes -, o popular e o erudito ocuparam lugares distintos e excludentes no cenário da cultura brasileira: o culto restou consagrado aos museus, academias, institutos de arte, grupos literários; e o popular - tratado, muitas vezes, pelo universo culto, como algo necessário a "que se deva conceder" (Matos, 1993) - ficou reservado às etnias, comunidades, "classes subalternas" (Gramsci, 1986) ou ao cotidiano vivido pelos trabalhadores. (BORELLI, 2001, p. 29).

Sobre pesquisas de recepção, Borelli aponta o trabalho realizado por ela, Lopes e Resende (2001), em que confirmaram a existência de um contrato de leitura ou, como ela mesma chama, de

\begin{abstract}
um pacto de recepção que prevê que os leitores/espectadores, possam se situar como sujeitos ativos, constitutivos e constituintes, dos processos de comunicação. Mediados por suas experiências cotidianas, e por repertórios que resultam de suas posições de classe, gênero, geração, etnia e formas de subjetivação, os receptores mergulham no fascínio das narrativas, histórias, enredos e personagens, reconhecendo os territórios de ficcionalidade, dialogando com as dimensões da vídeo-técnica, estabelecendo conexões de projeção e identificação e construindo uma competência textual narrativa (BORELLI, 2001, p. 34).
\end{abstract}

Isto retoma o que foi colocado por Abu-Lughod (2001) sobre o fato de a televisão compartilhar a efemeridade, estando associada ao entretenimento cultural, ou à propaganda estatal, ambos suspeitos. Ela pergunta: "a marca do status de vulgaridade e aparente banalidade da televisão impregnam aqueles que a estudam?” (ABU-LUGHOD, 2001, p. 105). A autora propõe um desafio aos antropólogos, que é experimentar maneiras de inserir a televisão de modo mais consistente no tipo de contexto social e cultural denso, que apenas o contínuo trabalho de campo antropológico é capaz de produzir, considerando que as formas culturais transmitidas por ela são deliberadamente produzidas, para pessoas em condições que variam política e historicamente (ABU-LUGHOD, 2001). A autora, ao analisar as telenovelas, recupera as noções de modernidade que envolvem a comunidade Egípcia, construindo um debate instigante sobre relações de gênero através da telenovela (ABU-LUGHOD, 2002). 
A premissa de que ver é privilegiado pelas sociedades ocidentais recai fortemente quando se trata de televisão, e da telenovela em especial. Como diria Comolli (2008), não se escapa da televisão; o documentário e o cinema escapam deste totalitarismo televisual.

O interior, o interno, o íntimo ultrapassam, então, o limite do visível. Nele, as câmeras estão em casa e filmam exatamente aquilo que sua presença produz. Pela magia do infravermelho, as próprias noites se tornam noites sem noite, sem sombra. Visível e invisível, campo e forade-campo: eu diria, em uma palavra, que o cinema se instituiu ao estabelecer um pacto sagrado entre luz e sombra. Esse pacto foi rompido pela telerrealidade. Ver tudo. Delírio pan-óptico dos senhores (COMOLLI, 2008, p. 199).

\section{A Direção de Jaime Monjardim}

Como bem demonstrou Jacob de Souza (2004, p. 64), "a telenovela é uma obra cultural comercial, que envolve um número grande de profissionais da produção simbólica (escritores, diretores, atores, cenógrafos, produtores de arte, figurinistas e outros)". A determinação "da autoria não é muito fácil já que, além de ser coletivamente produzida, ela é de longa duração e 'aberta' (elaborada ao longo da sua exibição), sendo por isso sensível às mais diversas interferências que podem mudar os rumos e a qualidade da narrativa audiovisual" (grifos meus). É correto dizer, segundo a autora, que a responsabilidade do produto é do diretorgeral e o do escritor, na medida em que o escritor conta a estória e o diretor a transforma em texto audiovisual.

A narrativa protagonista da novela constitui a estória de amor entre Jade (Giovanna Antonelli), uma muçulmana de origem marroquina, mas que cresceu afastada das práticas religiosas; e Lucas (Murílio Benício), um brasileiro, não é muçulmano. A tensão está no fato de ela ser muçulmana e, no Islam, o matrimônio de uma mulher muçulmana com um homem não muçulmano é proibido (a não ser que ele se converta à religião, como é comum acontecer no Brasil). Sobre isso, a 
resposta de Jamel, nome fictício de uma das minhas interlocutoras do bairro do Brás em São Paulo, é bem elucidativa, quando a indaguei sobre o matrimônio de uma muçulmana com um não-muçulmano: "água e óleo não se misturam", pontuando que, para ela, é impossível dar certo um casamento com uma pessoa que não partilhe da mesma cultura (religião) que a sua.

Para construir essa narrativa, o diretor de $O$ Clone se valeu de imagens de países islâmicos e de paisagens próximas (algumas das locações da telenovela eram nos Lençóis Maranhenses) e outras construídas como se fossem no Marrocos, de modo a trazer o espectador para perto deste universo e da história a ser contada. Deserto do Saara e construções antigas fazem parte desta construção imagética. As fotos a seguir mostram a paisagem marroquina.

\section{Foto 2: Cidade de Ouarzazate, Marrocos}

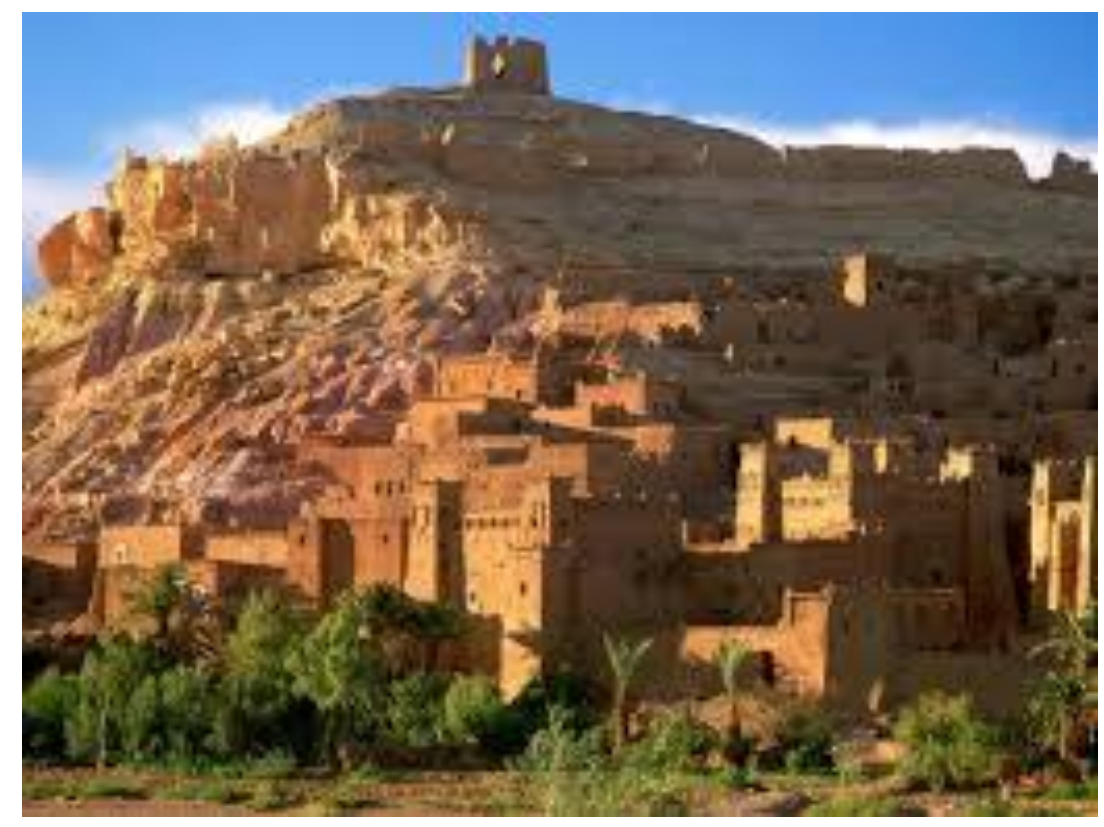

Fonte: Morroco, 2015 . 


\section{Foto 3: Curtume no Marrocos}

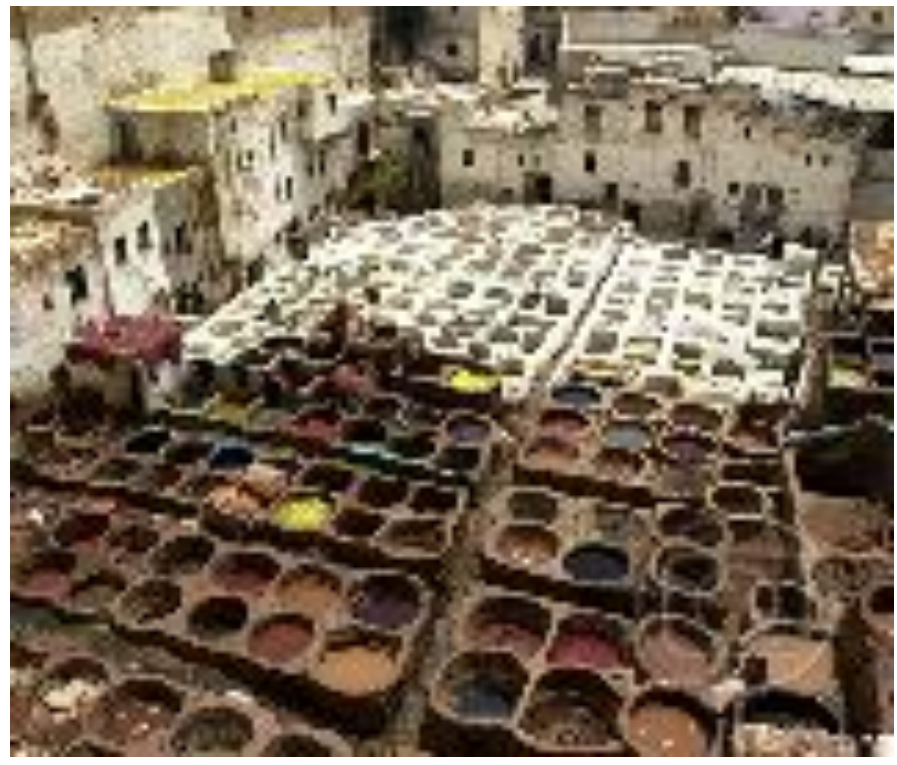

Fonte: PEREZ, 2015 .

\section{Foto 4: Deserto do Sahara no Marrocos}

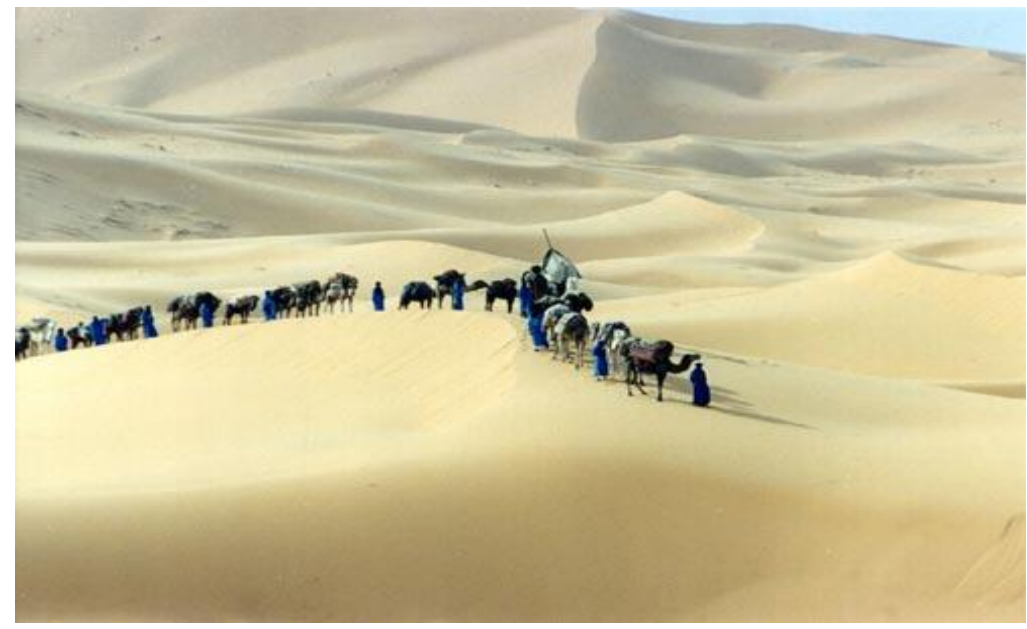

Fonte: MONJARDIM, 2015

O diretor Jayme Monjardim apresenta um estilo peculiar de direção, dando tons oníricos às cenas - longas ou slowmotion - e também pelo uso excessivo de closes, o que lhe rendeu inúmeras críticas. Este modo de dirigir/construir as 
imagens vem desde a telenovela Pantanal, da extinta Rede Manchete. Dirigir $O$ Clone significou para Monjardim o desafio de trazer para a TV brasileira uma novela que abordasse a cultura árabe e islâmica. A telenovela se passa parte em Fez, no Marrocos, e outra parte no Rio de Janeiro, lugares representados por suas belezas naturais, e as imagens construídas desses "paraísos" na terra despertam ainda mais o interesse dos espectadores. Algumas cenas foram gravadas em cinco cidades do Marrocos, onde o elenco permaneceu por 40 dias. Ouarzazate, cidade em que foram gravadas as cenas românticas de Jade e Lucas, é considerada a "Hollywood do deserto", por ter sido cenário para filmes como Gladiador (2000), de Ridley Scott; A joia do Nilo (1985), de Lewis Teajne; e a Última tentação de Cristo (1988), de Martin Scorcese.

Em Erfourd, às portas do deserto do Saara, Jayme Monjardim dirigiu uma sequência com uma caravana de 25 camelos e 12 beduínos, que se tornou uma das cenas marcantes da telenovela. Importante destacar a construção de uma cidade cenográfica na Central Globo de Produção: uma réplica em menor escala da Medina de Fez e outra simulando o bairro de São Cristovão, no Rio de Janeiro.

A estética visual proposta por Monjardim contribuiu para valorização não só das paisagens escolhidas, mas sugeriu também uma composição desses corpos (atores) que deveriam se moldar às paisagens marroquinas, o que se deixou entrever nas imagens deste artigo. Os atores deveriam penetrar de corpo e alma neste universo, a fim de compreender as sutilezas dos movimentos transmitidos pela cultura. Como afirma David MacDougall (2009, p. 64-65):

Ao enquadrarmos pessoas, objetos e eventos com uma câmera, estamos sempre falando "sobre" algo. É um modo de apontar, de descrever, de julgar. Domestica e organiza a visão... O enquadramento de um tipo mais geral produz diferentes modos de olhar com um câmera.

MacDougall (2009, p. 63) considera que as imagens construídas "são espelhos de nossos corpos, replicando o todo das atividades do corpo, com seus 
movimentos físicos, sua atenção que vai mudando de foco e seus impulsos conflitantes no sentido da ordem e da desordem [...]”. Neste sentido, considera que as "Imagens corporais não são apenas imagens de nossos corpos, elas são também imagens do corpo atrás da câmera e de suas relações com o mundo.” (MACDOUGALL, 2009, p. 63). Afirma ainda que os espectadores não podem evitar interpretar esses sinais, embora de modo inconsciente, na medida em que olhamos as coisas, nossa percepção é guiada pelos interesses culturais e pessoais. Entretanto, a percepção também constitui o mecanismo pelo qual esses interesses são alterados e ampliados.

Os protagonistas devem em algum momento serem felizes, mesmo que depois retornem à separação, mas esses momentos de despertar são quase o punctum, um fragmento que nos chama a atenção, conforme nos mostrou Barthes, em a Câmara Clara (2005), fazem com que nos concentremos em um determinado ponto, sem nos distrair. Punge o espectador por alguns instantes, talvez seja o Gozo lacaniano, conforme nos apontou Maria Rita Kehl quando diz que "a norma que rege o código da rede imaginária não é outra que o imperativo do gozo, e neste caso o discurso televisivo, revestido da autoridade de código social, exige a mesma coisa: o gozo, a plenitude, a locupletação” (1991, p. 66).

Um exemplo deste punctum barthiano é o beijo em telenovela. É ele que sela a interpretação dos personagens que suspende a trama do sofrimento, da separação e de outras mazelas que são contadas pela estória.

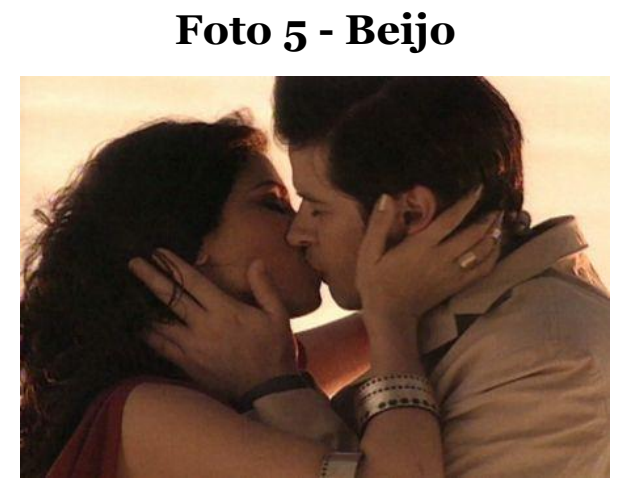

Fonte: EXTRA, 2015. 
Abu-Lughod (2003, p. 88) argumenta que o drama da televisão enfatiza as relações entre os personagens que sempre olham para o infinito enquanto a música evoca seus sentimentos interiores. Pode-se dizer que a música torna o espectador parceiro da cena, agente, e não meramente passivo, como se diz; ele está diante de uma cena e participa emocionamente dela, gostando ou não, emocionando-se ou não. A ideia de projeção ou identificação acontece porque há um ponto de contato desta imagem e/ou som, que desperta emoções e sensações em quem a vê/ouve. É a magia do audiovisual televisivo que nos captura. É certo que captura homens, mulheres, crianças, jovens e velhos, de modos diferentes, por isso, uma telenovela apresenta sempre vários núcleos de teledramaturgia, afinal é um programa para ser visto em família, em grupo, sozinho, abrangendo várias faixas etárias.

\section{Imagem}

“A imagem é universal, mas sempre particularizada" (AUMONT, 1995, p. 131).

Jacques Aumont (2009) considera que reconhecer alguma coisa em uma imagem é identificar, pelo menos em parte, o que nela é vista, com alguma coisa que se vê ou se pode ver no real. Além disso, a parte do espectador é projetiva. Isto vai ao encontro do que formulou Gombrich (1971): "a imagem age sobre o espectador", o que pressupõe que sua apreensão constitui a descoberta de estruturas profundas, que são as próprias estruturas mentais. Temos em Aumont que a ilusão será tanto mais eficaz quanto mais for buscada nas formas de imagens socialmente admitidas, até desejáveis; considera-se, portanto, que a ilusão é codificada socialmente.

O folhetim permitiu adentrar vários pontos que destaco agora: amor, divórcio, casamento, véu, casamento arranjado, comportamento de muçulmanos. 
Todos esses elementos foram pintados com cores fortes pela autora da novela, o que levou alguns muçulmanos, em certos momentos, a criticar veemente o rumo da trama. No entanto, outros não se incomodaram.

Foto 6 - Jade lendo
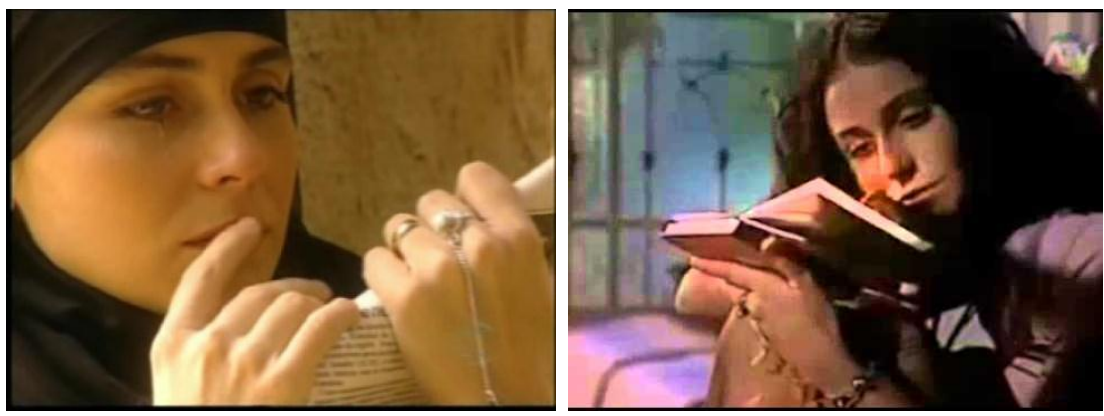

Fonte: DOOVI, 2015 ${ }^{\mathbf{a}}$

Em O Clone, Monjardim abusou das cenas em close, de modo que o espectador se fixasse no olhar das personagens, o que também é comum em outras telenovelas. Como define Abu-Lughod (2003), os closes usados nas telenovelas (soap opera) exercitam nas espectadoras a capacidade de entender sentimentos íntimos. Ainda, segundo a autora, o drama televisivo tenta produzir mimeticamente os estados interiores das pessoas, que sentem estas emoções através de close em expressões faciais e da atuação melodramática.

Imagens mais abertas em geral são das paisagens (Foz do Iguaçu e Rio de Janeiro). Isto nos leva a considerar que, em televisão, é no rosto que a expressão e a interpretação devem se revelar. Eu diria que em $O$ Clone a expressão mais forte está nos olhos dos amantes, são deles as imagens mais poéticas. É um olho que fala, que enuncia a paixão. Acompanhada da respiração ofegante da protagonista, quase sempre arfando, quando se encontra longe do amado.

As cenas que chamavam atenção, em conversas pelo Facebook ou comentários no Blog, eram as cenas nas quais Jade aparece chorando, por deixar 
Lucas, o que comovia as telespectadoras, muçulmanas ou não, que as consideravam as cenas mais belas, tanto pelo enquadramento quanto pela expressão dos atores. Sobre atuação em telenovela, o ator Claudio Marzo diz:

em novela cada capítulo é um happening, você faz e não sabe o que vai acontecer depois [...]. É tudo pronto, não tem um negócio assim: você vem aqui um dia e vai ter um ensaio e você discute, troca ideias, depois vai para sua casa, pensa, deixa amadurecer a coisa dentro de você, volta e grava. Não, não tem isso, você chega aqui e pronto: grava. (ORTIZ; BORELLI; RAMOS, 1989, p.151).

É muito comum a ideia de que o ator faz parte de uma engrenagem, que o envolvimento na produção e criação da cena é bastante limitado para ele, é quase uma produção em série, na qual o ator é mais uma peça. No entanto, o que se percebe é que o telespectador é capturado pela cena, portanto, a magia da imagem é realizada.

\section{0 véu (hijab)}

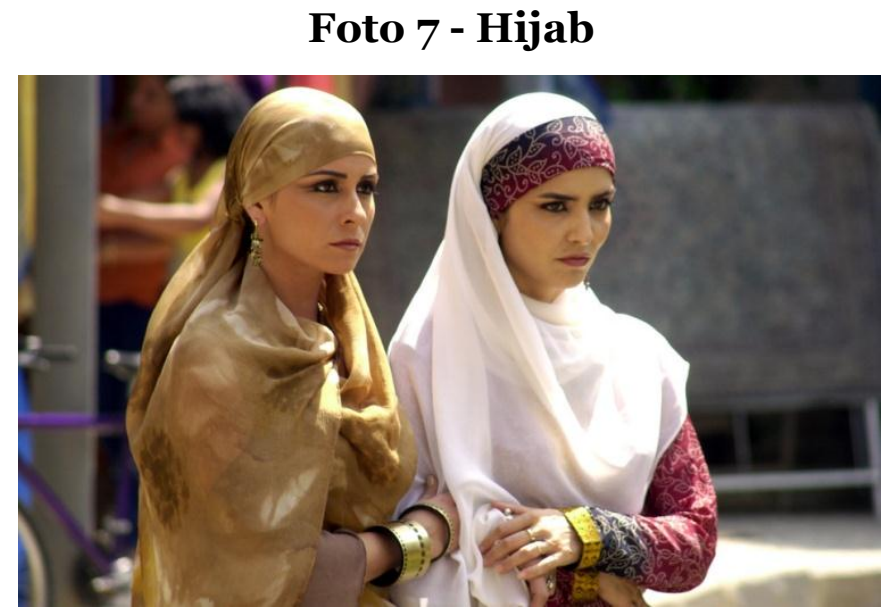

Fonte: SACCHITIELLO, 2013

Para "descobrir" as mulheres muçulmanas, a Antropologia tem que se "desvelar" de constrangimentos políticos imediatos (CARDEIRA DA SILVA, 2008, p. 137). 
Outro tópico para se pensar a visualidade em telenovela é a própria vestimenta. Neste caso, o véu islâmico, foi bem explorado, apresentando-se de várias cores e formatos e, em alguns momentos, víamos a explicação do seu uso como sendo uma obrigação religiosa. É fato que, quando se trata de imagem, o véu é a própria expressão da mulher muçulmana. As mulheres muçulmanas que apareciam na telenovela estavam sempre de véu, principalmente quando saíam às ruas, o que é usual em comunidades islâmicas. Dentro de casa, e na presença de parentes, a mulher não precisa usar o véu (hijab).

Conforme nos sugere Ortner (2007, p. 52), há “a intencionalidade como conceito que inclui todas as maneiras como a ação aponta, cognitiva e emocionalmente, para algum propósito”, e eu incluiria aqui, a própria experiência religiosa que pode variar de grupo a grupo, de muçulmanos a muçulmanos. O véu islâmico virou uma faixa tênue entre a opressão e a libertação. Compreender os vários discursos se faz necessário, no entanto, prefiro no momento me remeter às palavras de Nadia Hussein, quando da realização do vídeo Vozes do Islã: "Eu não me sinto oprimida por causa do meu véu, ao contrário...” (VOZES DO ISLÃ, 2007).

$\mathrm{Na}$ maior parte das cenas a protagonista (Jade) aparecia usando o hijab. Na primeira fase da novela, o uso do lenço era exclusivo no Marrocos. O seu modo de usar o lenço era um tanto peculiar, pois deixava à mostra os brincos, algo incomum entre as muçulmanas, que procuram usar jóias por baixo dos lenços. Durante a apresentação da novela em 2001 busquei atentar se havia, nas comunidades islâmicas em São Paulo, algum tipo de alteração em relação à vestimenta islâmica, principalmente, ao modelo e modo de usar o hijab. Pude verificar vários comentários em relação à beleza de Jade, e este modelo passou a ser visto com maior freqüência, principalmente entre as mulheres mais jovens e solteiras.

Quanto à novela, embora o véu tenha sido mostrado como uma peça que embeleza a mulher, levantou-se a questão da obrigatoriedade do seu uso a partir da primeira menstruação da menina, ao explorar uma situação em que Samira, muçulmana de 12 anos nascida no Brasil, escondia essa ocorrência de sua 
família, pois não queria usar o lenço. Desconsiderou-se as especificidades de regulamentação do código de vestimenta islâmico de cada país, o qual, por sua vez, varia mesmo dentro de um mesmo território nacional.

Ainda que muitas mulheres "revertidas" neste período não gostassem de ser associadas à Jade, é fato que o número de reversões ao Islã aumentou significativamente neste período, o que pude constatar de perto, visto que frequentava as aulas de religião para mulheres, ministradas por um Sheik de São Bernardo do Campo, e a cada aula mais jovens compareciam, sem nenhum conhecimento da religião. Infelizmente, não acompanhei o andamento dessas reversões; é bem possível que algumas tenham desistido da religião, mas certamente, outras permanecem até os dias de hoje.

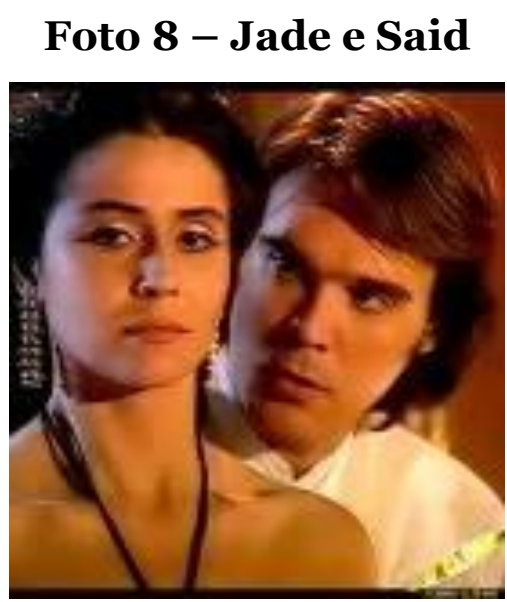

Fonte: FAMOUSFIX, 2015

Algo bastante comentado entre as mulheres, principalmente as solteiras, era o comportamento do Said, o marido de Jade, como exemplo de marido muçulmano, delicado, religioso, que vivia presenteando sua esposa. Há alusões de que as reversões de algumas mulheres tenham sido também em busca de um marido como Said. No entanto, não podemos descartar que a televisão também 
contribuiu para uma idealização, sugerindo comportamentos, modelos e de certa forma contribuindo para a construção da noção de pessoa, de sujeito. Conforme nos aponta Gomes (1998, p. 25), a telenovela tornou-se um gênero narrativo televisual exclusivo, predominantemente numa sociedade em que a escolarização deixa a desejar. Sendo, portanto, a principal forma de narrativa que a sociedade dispõe para expressar seus dramas sociais. Para a autora, as telenovelas foram transformadas num esquema de pensamento a partir do qual os brasileiros narram suas histórias, fictícias e reais. Portanto, sugerir um marido estrangeiro, com qualidades religiosas, também pode ser inserido neste pacote. É tão verdadeiro isto, que venho acompanhando com bastante interesse um número grande de casamentos entre brasileiras e estrangeiros muçulmanos; um dos trabalhos que oriento, trata justamente sobre este tema (PASQUALIN, 2013).

\section{Casamento/divórcio}

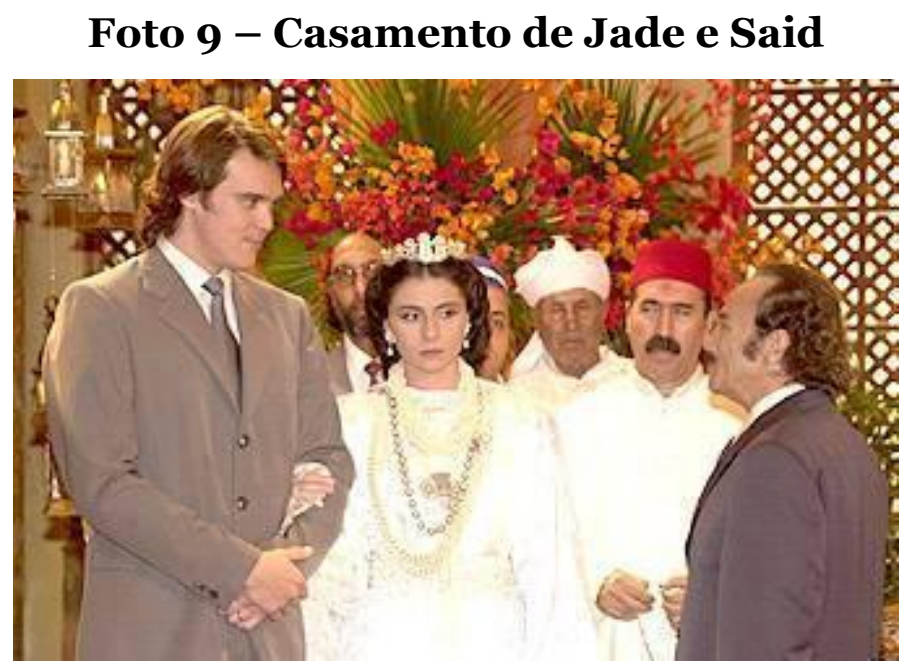

Fonte: MYSPACE, 2015.

Profeta disse: "Não há nada melhor para duas pessoas que se amam do que o casamento". 
No Islam, a regulamentação da vida amorosa se dá de modo bastante especifico, de modo que práticas como namorar e ficar, tão comuns no Brasil, não estão presentes. Quando uma pessoa se interessa por outra, ela fica noiva (khutba), o que se considera um semi-casamento - estágio em que os comprometidos podem conversar sozinhos, ir ao cinema, etc. É um compromisso definido entre as famílias, em geral com festa do noivado, conhecida como "urs" (núpcias) e a do casamento propriamente dita, chamada "walimah", acontece de três a sete dias após a consumação do casamento3.

Nas cenas de casamento arranjado dá-se destaque à imagem da noiva com expressão infeliz. Em $O$ Clone houve vários casamentos islâmicos e foram produzidos com muito requinte, desde o vestido da noiva, como em países árabes muçulmanos, cheio de brilhos, joias, e de várias cores, já que a noiva troca de roupa durante a cerimônia; assim como as danças, músicas e a assinatura do contrato de casamento lido pelo Sheik. A noite de núpcias foi representada de forma muito bonita com o noivo lavando os pés da noiva e recitando o alcorão. $\mathrm{O}$ contraponto que devemos fazer é a presença da família à porta do quarto do casal, esperando o lençol sujo de sangue da noiva, o que provaria sua virgindade. Jade, no entanto, não era mais virgem, o que provocou ira em Said, que, no entanto, cortou-se e gotejou seu sangue no lençol, de modo a evitar que o casamento fosse anulado.

Um dos temas mais explorados por Gloria Perez na trama foi o divórcio, um dos hadiths do Profeta Muhammad, que faz a seguinte ressalva: "De todas as coisas lícitas, a mais abominável para Allah é o divórcio". Ou seja, o divórcio é lícito, é possível, mas não é recomendado. A prática do mesmo se dá através do pronunciamento de repúdio por parte do marido, o qual deve ser repetido três vezes. A sua consumação, por sua vez, só pode ser realizada após três meses

\footnotetext{
${ }^{3}$ Vale a pena conferir o documentário produzido por Caiuby Novaes (1994) Wedding in Pakistan e o artigo produzido pela mesma autora (1996). A antropóloga acompanhou a família da noiva durante um mês, da preparação do casamento até a realização do mesmo. Se compararmos algumas cenas deste documentário e os cenários utilizados pelo diretor da novela há muita semelhançan, demonstrando similitudes.
} 
(período que possibilita verificar se a mulher não está grávida, sendo que, diante da constatação de uma gravidez, o divórcio só é permitido após o nascimento da criança) e os filhos, frutos do matrimonio dissolvido, devem ficar com a família do pai. Essas regras foram bem exploradas durante a novela, quando Jade se separa de Said e sofre por ter que se distanciar de sua filha, Khadija - dramaticidade e sofrimento que rendeu vários capítulos a trama.

\section{Foto 10 - Nazira}

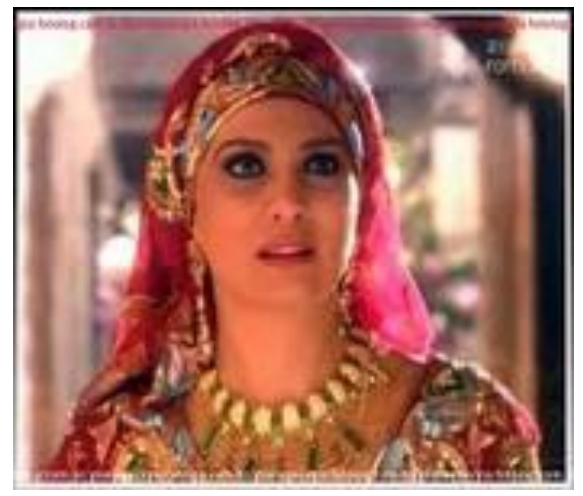

Fonte: DOOVI, 2015b

\section{Comportamento feminino}

O Clone (re)tratou as mulheres em dois tipos: o tradicional e o moderno. De um lado temos a personagem Latifa, prima de Jade, que faz tudo pelo marido, que o ama profundamente, embora tenha sido um casamento escolhido (arranjado) por seu tio, Ali. Vive a tradição - não atende homens em sua casa se está sozinha, dedica-se com afinco ao lar, aos filhos e ao marido. O seu maior receio é de que seu marido, Muhamed, um dia apresente interesse em esposar outra mulher. ${ }^{4}$

\footnotetext{
${ }^{4}$ Importante ressaltar que no Islã ao homem é permitido casar-se com até quatro mulheres, mas a poligamia é uma prática muito rara, de modo que os casamentos poligâmicos não representam nem 1\% dos matrimônios. Escassez que se deve as exigências para que tal pratica se realize, como a obrigação marital de oferecer as mesmas condições financeiras e afetivas a todas as esposas $A$ poligamia não é um tema fácil de discussão, há muitas controvérsias, recomenda-se apenas em um último caso, em situações de desamparo de mulheres e crianças, situações de guerra, por exemplo, mas há quem pense diferente dentro da comunidade. Alguns Sheiks preferem não realizar esses casamentos.
} 
Eliane Giardini interpretou a personagem Nazira, mulher que vivia a "tradição”, mas seu desejo era casar-se com quem aparecesse pela frente, passando toda a novela à procura de um pretendente muçulmano ou não. Era considerada espetaculosa, usava decotes e joias à mostra. Na religião, este tipo de comportamento é reprovado, privilegia-se a corporalidade do recato. As cenas gravadas por Giardini eram recheadas de humor, que quase sempre divertia os espectadores. Embora contrário ao comportamento esperado pelos muçulmanos, era divertido ver as artimanhas da personagem para conseguir marido a todo custo, assim como a dramatização que fazia diante dos irmãos que havia criado (Muhamad e Said), pois esses perderam a mãe cedo.

\section{Foto 11 - Dança}

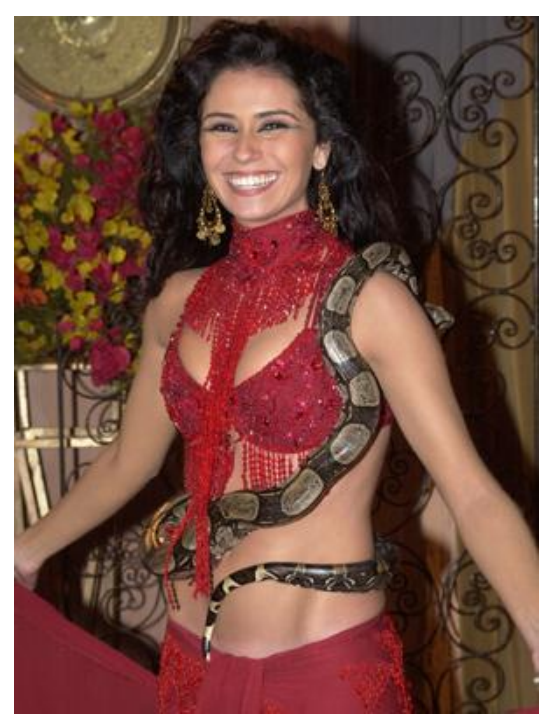

Fonte: PEREZ, 2013.

A telenovela delineava a mulher muçulmana a partir de dois parâmetros: o da elegância - com véus lindos, esvoaçantes, roupas e joias de requinte - e o da sensualidade - com as vestimentas de dança do ventre, cabelos volumosos, maquiagens sedutoras. A dança no Islam é permitida, mas se recomenda que homens e mulheres dancem em espaços distintos, o que, de modo geral, acontece. 
No entanto, pude participar de algumas festas nas quais os homens e as mulheres dançavam juntos. 5

No Islam a sexualidade não é pecado, ou mal vista, ao contrário, é importante e valorizada, de modo que se permite que a mulher dance para o marido e vice-versa. Faz parte do jogo de sedução a mulher se vestir com roupas especiais de dança, preparar o ambiente. Magda, minha primeira interlocutora em campo, disse-me certa vez que a mulher muçulmana se veste da porta para dentro. Neste sentido, a preocupação está em ser bonita para o marido, e comentou ainda que nós, brasileiras, tínhamos o hábito de nos arrumarmos da porta para fora, vestindo-nos de qualquer jeito para os maridos quando em casa.

No entanto, em O Clone, era possível ver mulheres dançando, em geral, com pouca roupa, o que causava incomodo nos muçulmanos. Estavam sempre bem bonitas e sedutoras, talvez pudéssemos discorrer mais sobre a feminilidade, ou o modo como os corpos femininos são construídos, tais como uma tecnologia de gênero construída pela telenovela.

A representação da mulher como imagem (espetáculo, objeto para ser apreciado, visão de beleza - e a correspondente representação do corpo feminino como lócus da sexualidade, cenário do prazer visual ou apelo ao olhar) é tão universal na nossa cultura, bem anterior e além da instituição do cinema, que necessariamente constitui um ponto de partida para qualquer entendimento da diferença sexual, seus efeitos ideológicos na construção dos sujeitos sociais e sua presença em todas as formas de subjetividade (LAURETIS, 1994, p.3)

Como forma de evidenciar alguns aspectos deste texto vale a pena conferir o clip da novela, pois este sintetisa o que foi mencionado até aqui.

${ }^{5}$ Em outro texto já relatei os comentários de algumas mulheres sobre dançar para o marido (FERREIRA, 2007). 


\section{Foto 12 - Clip da Novela}

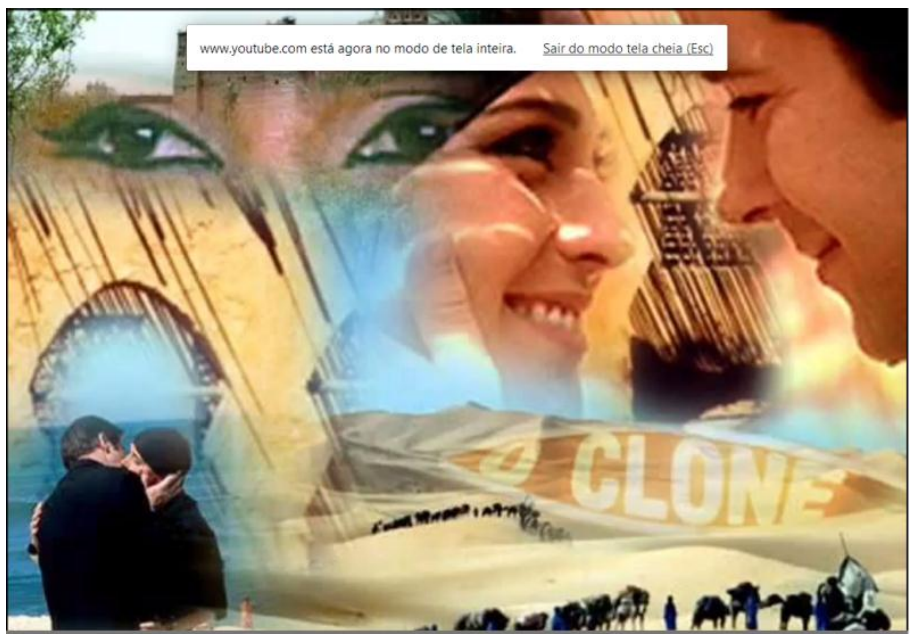

Fonte: O Clone - YouTube, 2015 .

O clip de entrada da novela evidencia alguns aspectos abordados neste texto. Apresenta cenas gravadas quando Lucas e Jade são jovens nas ruinas do Marrocos; depois vemos o casal separado, em suas respectivas cidades. O mar é a alusão que precisamos para saber que ele está de volta ao Rio de Janeiro. A imagem dela na ruína indica que ela permaneceu no Marrocos. As cenas são em close, focalizando o rosto da personagem, a lágrima que corre, a expressão de tristeza. A trilha sonora dá o tom de lamento. Este tipo de cena foi uma das mais exploradas no núcleo muçulmano: a separação e a união de Jade e Lucas. Passados 20 anos eles se encontram. É possível notar que a vestimenta, principalmente de Jade, está mais islâmica, o véu passa a ser explorado. No tempo 2:55' do clip vemos a respiração de Jane quando visualiza o seu amado. Todos esses ingredientes levam a uma absorção da cena por parte do espectador, que passa a acreditar - por meio dos olhares mostrados, dos closes e da trilha sonora que compoem o onirico do clip - na química dos atores, e para quem o beijo constitui, certamente, o ato-climax que produz o ápice da cena. 


\section{As frases de Tio Ali}

"Para nós, muçulmanos, o amor nasce da convivência para eles, ocidentais, o amor morre com a convivência".

Observar uma telenovela não é meramente ficar atento à recepção, mas sim, olhar para outros eixos desta mensagem, transmitida todos os dias, durante meses. Imagem, som e texto são fundamentais. Em $O$ Clone este pontos se entrelaçavam pelos discursos proferidos pelo Tio Ali (tio de Jade e de Latifa), respeitado por todos os muçulmanos da trama, que o consideravam culto e sensato.

As cenas mais esperadas pelos muçulmanos que assistiam à telenovela eram as cenas nas quais tio Ali pronunciava alguns ensinamentos religiosos. Muitas das expressões ditas por este personagem passaram a ser pronunciadas pelo público que acompanhava a telenovela, a ponto de dar origem a comunidades no Orkut. Maktub, Inshallah, haram, jogar ao vento, arder no mármore do inferno, etc. Fernando Brumana, em seu artigo "La palavra en Antropologia (Por uma antropologia-potlach)" discorre sobre a importância da palavra:

La palavra es empleada para construir la similitud de realidad, la verosimilitud, allí donde se pretende la recreación de lo experimentado, o, mejor, donde se construye literariamente una entidad unitaria y coherente a partir de la visión framentaria e impresionista dada por la experiencia individual do campo (BRUMANA, 2006, p. 43-44).

Deve-se levar em consideração o texto e as palavras ditas em cena, que marcam muitas vezes o entendimento das cenas e das atitudes das personagens. $\mathrm{O}$ campo do antropólogo visual é feito de imagens, mas não só, texto e imagem são potencialmente discursos, narrativas construídas. A palavra certa em um enquadramento, esteticamente perfeito, pode permitir ao telespectador compartilhar aquela experiência com a personagem, tornando-o mais íntimo da cena. 
Durante $O$ Clone uma frase em particular foi repetida várias vezes por tio Ali: "Que Allah te proteja de ti!”, em geral direcionada à sobrinha Jade, que passou a novela toda fazendo loucuras por um amor. Ele dizia: "Se te apaixonas estás colocando a inteligência a serviço dos sentidos”. Seus conselhos eram para que a jovem desistisse do romance e considerasse a família e a religião mais importante que uma aventura amorosa. "O amor chega e passa, a família fica”, completava Ali. Em momentos que Jade se sentia encurralada, e quando tornou-se prisioneira do marido, ele senteciava: "colhemos o que plantamos: plantas tempestade e colhes raios e trovões”.

Allah conhece todos os segredos e o que está além dos segredos. Ele sabe o que concebe cada fêmea e enxerga nas suas entranhas. Está escrito no Alcorão sagrado que Deus fez o homem de uma gota de sêmen e guardou essa gota em lugar seguro e 42 noites depois ele manda o anjo para modelar o que não tem forma. E o anjo vai fazendo os ouvidos, a carne, a pele, os ossos e quando termina pergunta: - Allah, "e esse vai ser homem ou mulher?”. E Allah responde o que ele quer que aquela pessoa seja. Só ele que é Deus pode criar a vida.

O sensível das palavras e das imagens é difícil de decifrar e, por isso, a dificuldade em sua escolha. Essa passagem pronunciada pelo personagem Ali, assim como tantas outras, são de uma sensibilidade admirável, o que se colocou como um desafio a mim no momento de seleciona-la.

$\mathrm{Na}$ novela era comum também a associação da mulher como esperta e geniosa. Em uma das conversas com Zoraide - sua governanta - e Jade, Sid Ali dizia:

Allah é justo, Zoraide, fez o homem mais forte, mais poderoso, mas deu a astúcia para mulher e com a astúcia muitas vezes elas vencem a força do homem. Jade, lembre-se o que diz o livro sagrado: os prazeres desse mundo são passageiros e os prazeres do paraíso são eternos. Allah disse para o Profeta: Oh Profeta, diz para suas esposas se elas ambicionam a vida desse mundo com seus enfeites, seus prazeres, elas terão. Se elas preferirem Deus e seu mensageiro, se elas quiserem o paraíso como última morada, Allah preparou para elas uma surpresa magnífica! "Se nascemos com uma boca e dois ouvidos, é porque devemos falar menos e ouvir mais". 
É importante destacar que na telenovela os personagens homens também apareciam com vestimentas típicas do Marrocos, sejam de árabes ou de berberes, como é o caso do turbante usado por tio Ali em uma das cenas da telenovela.

\section{Conclusão}

Como tratei no início deste artigo, a "invisibilidade" do Islam, no Brasil, diminuiu com a telenovela $O$ Clone. Evidentemente, não podemos atribuir essa maior visibilidade apenas a isso, visto que havia um contexto internacional onde o Islam e os países árabes estavam em destaque, sobretudo na grande mídia, o que fez com que as comunidades muçulmanas no Brasil se abrissem mais aos brasileiros, produzindo uma maior aproximação.

O "ibope" ascendente da novela sugere que foi positiva a aceitação dos telespectadores aos costumes árabes-muçulmanos ali retratados, talvez porque em telenovela as expressões, os objetos, são sempre reimpressos no cotidiano. Durante um período ouvi as pessoas dizerem inshallah (se Deus quiser), e comprarem as pulseiras usadas por Jade. A televisão, enquanto veículo de massa expoente, transmite rapidamente o que deseja e acaba inserindo modelos na sociedade. Em se tratando de $O$ Clone, parece-me que os efeitos foram prolongados, como demonstra o ibope da reprise da novela.

A imagem que o Ocidente produz sobre o Oriente, é como diria Edward Said (1996), delineada por estereótipos, muitas vezes romanceados - príncipes, sheiks milionários. No entanto, podemos dizer que $O$ Clone teve um papel preponderante na (re)contrução da relação da comunidade islâmica brasileira com os brasileiros, na medida em que possibilitou diminuir o estranhamento entre esses modos de ser. Sobre isso, em tom de brincadeira em uma entrevista sobre a telenovela, Sheik Jihad comenta que a novela foi boa, porque agora as pessoas pensam que os muçulmanos dançam e não que são terroristas. 
Se $O$ Clone fez sucesso foi porque, como afirma Comolli (2008, p. 198), a "realidade" que está em questão na televisão é reconstituída a partir de nossas projeções, pulsão e censuras, desejos e medos, por isso pode ser chamada de reflexo, espelho ou lixo. É uma janela aberta ao mundo mental, na qual o espectador é levado pelas imagens, sons e palavras, que o afetam de formas diversas. Outro dado importante a ser destacado é que embora seja uma ficção, uma narrativa longa de altos e baixos, trouxe para perto de nós elementos para reflexão que são trazidos a tona em cada drama vivido. A imagem como espelho reflete os sentimentos a serem compartilhados. Essa comunidade muçulmana [tendo como exemplo o núcleo da telenovela] é também modelo para nossa sociedade, mesmo diante do atentado às Torres Gêmeas. A telenovela contribuiu para essa aceitação, se foi dançando, ou por meio do amor de um casal, o fato é que a religião de alguma forma foi contemplada.

Outra invisibilidade que destacada foram os poucos trabalhos dedicados à telenovela na Antropologia Visual. É difícil diagnosticar os motivos desta ausência. Apresentei alguns elementos que talvez levem a outras pistas, sem buscar esgotar o tema. Entretanto, vejo uma porta aberta, no sentido que a imagem reflete não só corpos, mas pensamentos e estéticas variadas, de modo que estar atento a este universo é estar atento ao mundo audiovisual em sua plenitude. Não é possível descartar a televisão e, por conseguinte, a telenovela, na medida em que os desafios da imagem se colocam em vários campos e a televisão não está isenta disso.

\section{REFERÊNCIAS}

ABU-LUGHOD, Lila. A interpretação de cultura(s) após a televisão. Cadernos de Antropologia e Imagem, Rio de Janeiro, n. 13, p. 103-129, 2001.

ABU-LUGHOD, Lila. El matrimonio del feminismo y el islamismo em Egito: el repudio selectivo como dinamica de la politica cultural poscolonial. In: ABU-LUGHOD, Lila (Org.). Feminismo y modernidade em Oriente Proximo. Madrid: Catedra, 2002. p.355394 . 
ABU-LUGHOD, Lila. Melodrama Egípcio: uma tecnologia do sujeito moderno? Cadernos Pagu, Campinas, n. 21, p. 75-102, 2003.

ALMEIDA, Heloisa Buarque de. Consumidoras e heroínas: gênero na telenovela. Estudos feministas, Florianópolis, v. 15, n. 1, p. 177-192, 2007.

ALMEIDA, Heloisa Buarque de. Famílias diante das telenovelas. Cadernos de Antropologia e Imagem, Rio de Janeiro, n. 17, p. 283-299, 2003.

ALMEIDA, Ronaldo. Religião em transição. In: DUARTE, Luis Fernando (Org.). Horizontes das ciências sociais no Brasil. Antropologia. São Paulo: Discurso Editorial/ANPOCS, 2010. p. 366-405.

AUMONT, Jacques. A Imagem. 14.ed. Campinas, SP: Papirus, 2009.

BARTHES, Roland. A câmara clara. Lisboa: Edições 70, 2005.

BORELLI, Silvia Helena Simões. Ação, suspense, emoção: literatura e cultura de massa no Brasil. São Paulo: EDUC/Estação Liberdade/FAPESP, 1996.

BORELLI, Silvia Helena Simões. Telenovelas brasileiras: balanços e perspectivas. São Paulo em Perspectiva, São Paulo, v. 15, n. 3, p. 29-36, 2001.

BOUHDIBA, Abdelwahab. A sexualidade no Islã. São Paulo: Globo, 2006.

BOURDIEU, Pierre. As regras da arte. São Paulo: Companhia das Letras, 1996.

BOURDIEU, Pierre. Sobre a Televisão, seguido de A influência do jornalismo e Os Jogos Olímpicos. Rio de Janeiro, Jorge Zahar, 1997.

BRUMANA, Fernando Giobellina. La palabra en antropología. Ilha Revista de Antropologia, Florianópolis, v. 8, n. 1,2, p. 041-071, jan. 2006. ISSN 2175-8034. Disponível em: <https://periodicos.ufsc.br/index.php/ilha/article/view/18221>. Acesso em: 30 Mar. 2015. doi:http://dx.doi.org/10.5007/18221.

CAIUBY NOVAES, Sylvia. O Brasil em imagem: caminhos que antecedem e marcam a antropologia visual no Brasil. In: DUARTE, Luis Fernando (Org.). Horizontes das ciências sociais no Brasil. Antropologia. São Paulo: Discurso Editorial/ANPOCS, 2010. p. 457-487.

CAIUBY NOVAES, Sylvia. Um casamento no Paquistão: na captura de imagens.

Cadernos de Antropologia e Imagem, Rio de Janeiro, n. 3, p. 107-115, 1996.

COMOLLI, Jean-Louis. Ver e Poder - a inocência perdida, cinema, televisão, ficção, documentário. Belo Horizonte: Editora UFMG/Humanitas, 2008.

EDITORA GLOBO. Um outro olhar - o mundo árabe e o islã através da novela O Clone. Rio de Janeiro: Globo, 2002. 
ESPINOLA, Claúdia, Voigt. O véu debaixo da linha do equador. As mulheres da comunidade islâmica de Florianópolis. In: RIAL, Carmem; TONELI, Maria Juracy F. (Org.). Genealogias do silêncio: feminismo e gênero. Florianópolis: Ed. Mulheres, 2004. p.131-152.

ESPINOLA, Claúdia, Voigt. O véu que (des)cobre: etnografia da comunidade árabe muçulmana em Florianópolis. 2005. 238f. Tese Doutorado (Antropologia Social), UFSC, Florianópolis, 2005.

FERREIRA, Francirosy C. Barbosa. Entre Arabescos, luas e tâmaras: performances islâmicas em São Paulo. 372f. Tese de Doutorado. PPGAS USP. Antropologia, 2007.

FERREIRA, Francirosy Campos Barbosa. Experiências com Islã: as intelectuais nas mesquitas. Interseções: Revista de Estudos Interdisciplinares, Rio de Janeiro, ano 11, n. 2, p. 261-289, 2009 a.

FERREIRA, Francirosy Campos Barbosa. Mais de mil e uma noites de experiência etnográfica: uma construção metodológica para pesquisadores-performers da religião. Etnográfica, Lisboa, v. 13, n. 2, p. 439-464, 2009 b.

FERREIRA, Francirosy Campos Barbosa. Olhares femininos sobre o Islã: etnografias, metodologias e imagens. São Paulo: Hucitec, 2010.

FERREIRA, Francirosy Campos Barbosa. Redes islâmicas em São Paulo: nascidos muçulmanos x revertidos. Revista Litteris, Rio de Janeiro, v. 3, p. 1-27, 2009 c. Disponível em: <http://antropologiasocial.com.br/wpcontent/uploads/2010/10/redesislamicasemsaopaulo.pdf > . Acesso em: 5 de maio de 2011.

GEERTZ, Clifford. Nova luz sobre a Antropologia. Rio de Janeiro: Jorge Zahar Editor, 2001.

GEERTZ, Clifford. A interpretação das culturas. Rio de Janeiro: Jorge Zahar, 1989.

GOMBRICH, Ernst H. L’art et l’illusion (1959). Gallimard, 1971.

GOMES, Laura Graziela Figueiredo Fernandes. Novela e sociedade no Brasil. Niterói: EdUFF, 1998.

GOMES, Laura Graziela. Telenovela e cultura da harmonia. In: KUNSCH, M. M. K.; FISCHMANN, R. (Orgs.). Mídia e tolerância - a ciência construindo caminhos de liberdade. São Paulo: EDUSP, 2002. p. 75-88.

GONÇALVES, Marco Antonio; HEAD, Scott (Org.). Devires imagéticos: a etnografia, o outro e suas imagens. Rio de Janeiro: 7Letras. 2009.

HAMBURGER, E. I. Vale tudo e as consequências não antecipadas da modernização. Imagens (Campinas), Campinas, v. 8, p. 36-44, 1998. 
HAMBURGER, E. I. A expansão do feminino no espaço público brasileiro: novelas de televisão nas décadas de 1970 e 80. Revista Estudos Feministas, Florianópolis, (UFSC. Impresso), v. 15, p. 153-175, 2007.

HAMID, Sônia. Entre a guerra e o gênero: memória e identidade de mulheres palestinas no Brasil. Brasilia, DF, Universidade de Brasília, tese de mestrado, 2007.

JACOB DE SOUZA, Maria Carmem. Telenovela e representação social. Rio de Janeiro: E-Papers Serviços Editoriais, 2004.

JACOB DE SOUZA, Maria Carmem Representação do popular e campo da telenovela: histórias e história de Benedito Ruy Barbosa. In: XXIV Encontro anual da ANPOCS, GT1 - Biografia e Memorial Social , Petrópolis, 2000.

KEHL, Maria Rita. Imaginar e pensar. In: NOVAES, Adauto. Rede imaginária televisão e democracia. São Paulo: Companhia das Letras, 1991. p. 60-73.

LAURETIS, Tereza. A tecnologia de gênero. In: HOLANDA, H. B. (Org.). Tendências e impasses: o feminismo como crítica cultural. Rio de Janeiro: Rocco, 1994. p. 206-242.

LEAL, Ondina Fachel. A leitura social da novela das oito. Petrópolis, RJ: Vozes, 1986.

LOPES, M.I.V.; BORELLI, S.H.S. e RESENDE, V. da R. (Coord.). Vivendo com a telenovela: mediações, recepção, teleficcionalidade. São Paulo: Summus Editorial, 2001.

MACDOUGALL, David. Significado e ser. In: BARBOSA, A.; CUNHA E.; R. S. HIKIJI (Orgs.). Imagem-conhecimento: antropologia, cinema e outros diálogos. Campinas: Papirus, 2009. p. 61-84.

MARQUES, Vera Lucia Maia. Sobre práticas religiosas e culturais islâmicas no Brasil e em Portugal: notas e observações de viagem. 2009. Tese (Doutorado em 2009), Departamento de Sociologia, Universidade Federal de Minas Gerais, Belo Horizonte, 2009.

MONTENEGRO, Silvia. Telenovela et identités musulmanes au Brésil. Revue Lusotopie - Médias, pouvoir et identités, 2004, Leiden, The Netherlands, p. 243-260, 2004. Disponível em: <http://www.lusotopie.sciencespobordeaux.fr/montenegro2004.pdf>. Acesso em: 19 maio 2011.

NADER, Laura. Harmony ideology - justice and control in a Zapotec Mountain Village. California: Stanford University, 1990.

NOVAES, Adauto. O olhar melancólico. In: NOVAES, Adauto. Rede Imaginária televisão e democracia. São Paulo: Companhia das Letras, 1991. p. 85-90.

ORTIZ, Renato; BORELLI, Silvia H. S; RAMOS, J. M. O. Telenovela - história e produção. São Paulo: Brasiliense, 1989. 
ORTNER, Sherry B. Poder e projetos: reflexões sobre a agência. In: GROSSI, Miriam; ECKERT, Cornelia; FRY, Peter (Orgs.). Conferências e diálogos: saberes e práticas antropológicas. Blumenau: Nova Letra, 2007. p. 45-80.

PASQUALIM, Flávia, A. Encantos e Desencantos: casamentos de mulheres brasileiras com homens turcos muçulmanos. Projeto de Doutorado, Programa de Pós-Graduação em Psicologia, USP/FFCLRP, 2013.

PEREIRA, Pedro Paulo Gomes. Violência e tecnologias de gênero: tempo e espaço nos jornais. Revista Estudos Feministas, Florianópolis, v. 17, n. 2, p. 485-503, maioagosto, 2009.

PINTO, Paulo Gabriel Hilu da Rocha. Islã: religião e civilização - uma abordagem antropológica. Aparecida, SP: Santuário, 2010.

PINTO, Tiago de Oliveira. Som e música. Questões de uma antropologia sonora. Revista de Antropologia, São Paulo, v. 44, n. 1, p. 222-286, 2001.

REIS, Alice Casanova. O feminino na dança do ventre: uma Análise Histórica sob uma perspectiva de Gênero. Divers@ Rev. Elet. Interdisc., Matinhos, v.1, n.1, p.56-67, jul./dez.2008.

SAID, Edward. Orientalismo - o oriente como invenção do ocidente. São Paulo: Companhia das Letras, 1996.

VALDIGEM, Catarina. Usos da telenovela brasileira O Clone em Portugal: fragmentos da construção da identidade. In: INTERCOM - Sociedade Brasileira de Estudos Interdisciplinares da Comunicação. Congresso Brasileiro de Ciências da Comunicação, 28. 2005, Rio de Janeiro: 2005. Disponível em <http://www.intercom.org.br/papers/nacionais/2005/resumos/R1913-1.pdf>. Acesso em: o9 maio 2009.

\section{FOTOGRAFIAS E FILMOGRAFIA}

A WEDING IN PAKISTAN. Dirigido por Sylvia Caiuby Novaes. Grã-Bretanha: 2004, 46', NTSC, cor.

ALLAHU AKBAR. Dirigido por Francirosy C.B.Ferreira. São Paulo: LISA, 2006, 29', NTSC, cor.

AL-MASOON, WONDER WOMEN. Dirigido por Sylvia Caiuby Novaes. Grã-Bretanha: 2004, 25', NTSC, cor.

CADERNOS DE DANÇA. Tag Archives: O Clone. Disponível em: <https://cadernosdedanca.wordpr ess.com/tag/o-clone/>. Acesso em: 25 mar. 2015. 
DOOVI. Casamento de Said O Clone. Foto Jade lendo. Disponível em:

<http://www.doovi.com/search/casamento\%20de\%20said\%200\%20clone>. Acesso em: 25 mar. 2015a.

DOOVI. O Clone - Jade Nazira Ranya. Disponível em: <http://www.doovi.com/video/oclone-jade-nazira-ranya/i7fDK8JmNpA>. Acesso em: 25 mar. 2015b.

EXTRA. Giovanna Antonelli e Murilo Benício, que já foram casados na vida real, voltarão a ser par romântico na TV

Disponível em: <http://extra.globo.com/famosos/giovanna-antonelli-murilo-benicio-queja-foram-casados-na-vida-real-voltarao-ser-par-romantico-na-tv-14943066.html>. Acesso em: 25 mar. 2015.

FAMOUSFIX. Giovanna Antonelli and Dalton Vigh.Disponível em: < http://dating.famousfix.com/tpx_5671272/giovanna-antonelli-and-dalton-vigh/>. Acesso em: 25 mar. 2015.

MONJARDIM, Jayme. Galeria de fotos. As mais belas imagens que embalaram essa trama. Cenas no Deserto do Sahara. Disponível em:

<http://www.jaymemonjardim.com.br/clone/galeria/conteudo.htm>. Acesso em: 25 mar. 2015.

MORROCO. Morrocco Forums. Ouarzazate. Disponível em:

<http://www.magicmorocco.com/ouarzazate_morocco.html>. Acesso em: 25 mar. 2015.

MYSPACE. O Clone. Photos. Disponível em: <https://myspace.com/clonperu/photos >. Acesso em: 25 mar. 2015.

O CLONE - Canção de Jade e Lucas (Brasil). YouTube. Disponível em: <https://www.youtube.com/watch?v=U5b37yRvKeU>. Acesso em 31 mar. 2015.

PEREZ, Glória. De tudo um pouco. Sobre protagonistas. May 18, 2013. Disponível em: <http://gloriaperez.com.br/sobre-protagonistas/>. Acesso em: 25 mar. 2015.

PEREZ, Glória. Memória Globo. Fotos. Disponível em:< http://memoriaglobo.globo.com/perfis/talentos/gloria-perez/gloria-perez-o-brasil-e-omundo.htm>. Acesso em: 25 mar. 2015.

PEREZ, Glória. O Clone. Direção Jaime Monjardim e Marcos Schechtman. Exibida entre $1^{\circ}$ de outubro e 15 de junho 2002. Rede Globo. No de episódios: 221.

SACCHITIELLO, Barbara. Novelas para gringo ver. Meio \& Mensagem. 28 jan. 2013. Foto: Divulgação/TV Globo. Disponivel em:

<http://www.meioemensagem.com.br/home/midia/noticias/2013/01/28/Novelas-paragringo-ver.html>. Acesso em: 25 mar. 2015.

SACRIFÍCIO. Dirigido por Francirosy C.B.Ferreira. São Paulo: LISA, 2007, 13’, NTSC, cor. VOZES DO ISLÃ. Dirigido por Francirosy C.B.Ferreira. São Paulo: LISA, 2007, 25’, NTSC, cor. 